\title{
The possibilities of pharmacological intervention in myopia
}

\author{
Maciej Czepita ${ }^{1}$, Elena N. Iomdina $\left(^{2}\right.$ \\ ${ }^{1}$ Private Practice, Szczecin, Poland \\ ${ }^{2}$ Helmholtz National Medical Research Center of Eye Diseases, Russian Ministry of Health, Moscow, Russia
}

\begin{abstract}
This paper presents and discusses the current possibilities of pharmacological intervention in myopia. A review of the latest literature regarding the pharmacological treatment of myopia has been presented.

The results of experimental research on the potential use of: atropine, oxyphenonium, pirenzepine, chlorpyrifos, apomorphine, reserpine, 6-hydroxy dopamine, dextromethorphan, MK-801, APV, bicuculline, SR95531, CACA, TPMPA, dextrophanol, levorphanol, $D$ - and $L$-naloxane, $L$-NAME, formoguanamine, b-xyloside, the central and peripheral antagonist of VIP, basic fibroblast growth factor, a solution of the basic amino acid salts in the form of succinates, in the treatment of myopia have been described. The clinical use of pirenzepine,7-methylxanthine, and atropine has been discussed.

The obtained results of experimental and clinical studies give hope that a new effective pharmacological method of myopia treatment can be discovered soon.
\end{abstract}

KEY WORDS: myopia; treatment; pharmacology

Ophthalmol J 2020; Vol. 5, 150-153

\section{INTRODUCTION}

It is believed that currently about $1 / 4$ of adults and $1 / 3$ of children worldwide have myopia. This type of refractive error is the most prevalent in Asian and highly developed countries. The development of myopia is related to genetic predispositions and environmental factors. Among the environmental factors, reading, writing, and computer use have the most influence [1-4].

Although myopia is such a significant social problem, no effective treatment method has so far been developed. Various treatment methods or their combinations have been proposed so far for school myopia and progressive myopia $[1,3]$.

Due to myopia's high social importance and considerable interest in the latest experimental and clinical results, the authors present a review of the current opinions concerning the issue.

\section{RESULTS OF EXPERIMENTAL STUDIES}

Research into experimental myopia was started by Young [5] in 1961. The researcher noticed that monkeys develop myopia if kept in a closed space. In 1975, Hubel and Wiesel from Harvard University, while researching the plasticity of the visual cortex, discovered by chance that suturing of the eyelids in young monkeys leads to an increase in the axial length of the eye. In 1981, Hubel and Wiesel were awarded the Nobel Prize for their research into the visual cortex's structure and function. A substantial enlargement of the eye after tarsorrhaphy was not related to their work. However, they immediately concluded that this finding could be of clinical value. Therefore, they conducted extensive control studies, which they later proved through clinical observations. They observed a higher prevalence of myopia in children with ptosis and corneal scars [6]. 
In 1977, intensive work on the role of tarsorrhaphy or occlusion on the development of form-deprivation myopia was started. Many experiments on monkeys, cats, rabbits, guinea pigs, shrews, squirrels, chickens, and kestrels were conducted in almost 25 laboratories worldwide. The research, conducted in this field by Raviola and Wiesel from Harvard University, Laties and Stone from the University of Pennsylvania, Wallman from the City University of New York, and Schaeffel from the University of Tübingen $[7,8]$ deserve special mention. In 1988, Schaeffel et al. [9] discovered that experimental myopia develops due to diffusing lenses usage. In the same year, Stone et al. [10] observed that tarsorrhaphy induces metabolic changes in the retina and, therefore, initiated research to find substances inhibiting the development of experimental myopia.

\section{SUBSTANCES INHIBITING THE PROGRESSION OF MYOPIA}

Based on experimental results, researchers from around the world tried to establish which substances could be used in the treatment of myopia. Currently, the following substances have been found to inhibit the progression of experimental myopia:

- atropine, oxyphenonium - non-selective antagonists of the muscarinic receptors [11-13];

- pirenzepine - an antagonist of the muscarinic M1 receptors [14-16];

- chlorpyrifos - a substance inhibiting acetylcholinesterase [17];

- apomorphine - a non-selective agonist of the dopamine receptors $[18,19]$;

- reserpine - an alkaloid of rauwolfia hampering the storage of catecholamines and serotonin in both the central and peripheral nervous system [20];

- 6-hydroxydopamine - a substance inhibiting hydroxylase of tyrosine and destroying the structure of the adrenergic endings [21-23];

- dextromethorphan, MK-801, APV - antagonists of the NMDA receptors [24];

— bicuculline, SR95531 — antagonists of the GABAA receptors [25];

- CACA, TPMPA - antagonists of the GABAAOr receptors [25];

- dextrophanol, levorphanol, $D$ - and $L$-naloxane $-D$ - and $L$-enantiomers acting at opioid receptors [26];
- L-NAME - a nitric oxide synthase inhibitor $[27,28]$;

- formoguanomine - a substance inhibiting the production of proline and glutamate, leading to the fall of the thickness of the choroid, degenerative changes in the photoreceptors and the pigment epithelium of the retina [29];

— b-xyloside - a proteoglycan synthesis inhibitor [30];

— central antagonist of VIP - a hybrid peptide consisting of the C-terminal of the VIP molecule linked serially to the $\mathrm{N}$-terminal portion of neurotensin [31];

- peripheral antagonist of VIP — 4Cl-D-Phe6, Leu17 [31];

— basic fibroblast of growth factor — a growth factor connected with heparin [32];

- a solution of the basic amino acid salts in the form of succinates [33].

Due to the pathogenesis of experimental myopia, which in many different aspects closely resembles the pathogenetic mechanism of progressive myopia in humans, all the substances listed above can be viewed as potential medications inhibiting myopia's progression in children and adolescents.

\section{RESULTS OF CLINICAL STUDIES}

In 2004 Siatkowski et al. [34] from the University of Oklahoma examined 277 US children aged 8-12 with myopia between -0.75 to $-4.0 \mathrm{D}$. These children were given topical 2\% pirenzepine gel twice a day. After a year of use, the progression of myopia decreased by $51 \%$.

The results of Siatkowski et al. [34] were reaffirmed in 2005 by Tan et al. [35] from the Singapore Eye Research Institute. They examined 353 children from Singapore, Taiwan, and Hong Kong aged 6 to 12 with myopia between -0.75 to $-4.0 \mathrm{D}$. The authors observed that pirenzepine slowed the yearly progression of myopia by $44 \%$.

In 2008, Siatkowski et al. [36] examined 84 American children aged 8-12 with myopia between -0.75 and $-4.0 \mathrm{D}$. The children received topical 2\% pirenzepine gel twice daily. After two years of treatment, the progression of myopia decreased by $41 \%$.

In the same year, Trier et al. [37] from Trier Research Laboratories in Copenhagen examined 107 Danish children aged 8 to 13 with myopia above $-0.75 \mathrm{D}$. The children received an oral dose of $0.4 \mathrm{~g}$ of 7 -methylxanthine once daily. After three 
years of treatment with 7-methylxanthine, they revealed a lower progression of myopia.

In 2012 Chia et al. [38] from the Singapore Eye Research Institute examined 400 children from Singapore aged between 6 and 12 years of age with myopia higher than $-2.0 \mathrm{D}$. After two years of treatment with a topical $0.01 \%$ solution of atropine, they noted a decrease of $0.5 \mathrm{D}$ of myopia per year.

Following these studies, a mass-scale use of atropine in myopia treatment in many countries has been observed. It has been found that a $0.01 \%$ solution of atropine decreases the development of myopia and does not induce side effects in the anterior segment [39-42]. It has also been observed that $0.02 \%$ atropine eye drops had a better effect on myopia progression than $0.01 \%$ atropine. However, both showed similar effects on pupil diameter and accommodative amplitude after 12 months of treatment [43]. Over two years, the observed efficacy of $0.05 \%$ atropine was twice as high as $0.01 \%$ atropine. It remained the optimal concentration among the studied atropine concentrations in slowing myopia progression [44].

In Poland, studies into the role of atropine in myopia’s progression were initiated by Koronczews$\mathrm{ka}$ in the 1980s. Regretfully, the author used $0.5 \%$ atropine, which led to severe side effects. Currently, research by Grzybowski is ongoing [45, 46].

Other substances used in the above-mentioned experimental studies to slow down the eye growth during myopia development up to this day have not been attempted in clinical practice.

\section{CONCLUSION}

The obtained results of experimental and clinical studies are promising enough and raise hope that a new effective pharmacological method of myopia treatment can be discovered soon.

\section{REFERENCES}

1. Czepita D. Myopia: incidence, pathogenesis, management and new possibilities of treatment. Russ Ophthalmol J. 2014; 7(1): 96-101.

2. Czepita $M$, Czepita D, Lubiński W. The Influence of Environmental Factors on the Prevalence of Myopia in Poland. J Ophthalmol. 2017; 2017: 5983406, doi: 10.1155/2017/5983406, indexed in Pubmed: 29348929.

3. Morgan IG, Ohno-Matsui K, Saw SM, et al. Myopia. Lancet. 2012; 379(9827): 1739-1748, doi: 10.1016/S0140-6736(12)60272-4, indexed in Pubmed: 22559900.

4. Zadnik K, Mutti DO. Incidence and distribution of refractive anomalies. In: Benjamin WJ, Borish IMO. ed. Borish's clinical refraction. Elsevier, Butterworth Heimann, St Louis 2006: 35-55.

5. Young FA. The effect of restricted visual space on the primate eye. Am J Ophthalmol. 1961; 52: 799-806, doi: 10.1016/0002-9394(61)90904-7, indexed in Pubmed: 14009335.
6. Raviola E, Wiesel TN, Raviola E, et al. An animal model of myopia. N Engl J Med. 1985; 312(25): 1609-1615, doi: 10.1056/ NEJM198506203122505, indexed in Pubmed: 4000200.

7. Goss DA. Development of the ametropias. In: Benjamin WJ, Borish IM. ed. Borish's clinical refraction. Butterworth Heimann, Elsevier, St Louis 2006: 56-92.

8. Norton TT, Norton TT. Animal Models of Myopia: Learning How Vision Controls the Size of the Eye. ILAR J. 1999; 40(2): 59-77, doi: 10.1093/ ilar.40.2.59, indexed in Pubmed: 11304585.

9. Aleman A, Schaeffel F, Tepelus TC, et al. Accommodation, refractive error and eye growth in chickens. Vision Res. 1988; 28(5): 639-657, doi: 10.1016/0042-6989(88)90113-7, indexed in Pubmed: 3195068.

10. Stone RA, Laties AM, Raviola $E$, et al. Increase in retinal vasoactive intestinal polypeptide after eyelid fusion in primates. Proc Natl Acad SciUS A. 1988; 85(1): 257-260, doi: 10.1073/pnas.85.1.257, indexed in Pubmed: 2448769.

11. Luft WA, Ming Y, Stell WK, et al. Variable effects of previously untested muscarinic receptor antagonists on experimental myopia. Invest Ophthalmol Vis Sci. 2003; 44(3): 1330-1338, doi: 10.1167/iovs.02-0796, indexed in Pubmed: 12601066.

12. McBrien NA, Moghaddam HO, Reeder AP, et al. Atropine reduces experimental myopia and eye enlargement via a nonaccommodative mechanism. Invest Ophthalmol Vis Sci. 1993; 34(1): 205-215, indexed in Pubmed: 8425826.

13. Stone RA, Lin T, Laties AM, et al. Muscarinic antagonist effects on experimental chick myopia. Exp Eye Res. 1991; 52(6): 755-758, doi: 10.1016/0014-4835(91)90027-c, indexed in Pubmed: 1855549.

14. Cottriall CL, McBrien NA, Cottriall CL, et al. The M1 muscarinic antagonist pirenzepine reduces myopia and eye enlargement in the tree shrew. Invest Ophthalmol Vis Sci. 1996; 37(7): 1368-1379, indexed in Pubmed: 8641840.

15. Leech EM, Cottrial CL, McBrien NA. Pirenzepine prevents form deprivation myopia in a dose dependent manner. Ophthal Physiol Opt. 1995; 15(5): 351-356, indexed in Pubmed: 8524553.

16. Rickers $M$, Schaeffel F. Dose-dependent effects of intravitreal pirenzepine on deprivation myopia and lens-induced refractive errors in chickens. Exp Eye Res. 1995; 61(4): 509-516, doi: 10.1016/s00144835(05)80147-2, indexed in Pubmed: 8549693.

17. Geller AM, Abdel-Rahman AA, Peiffer RL, et al. The organophosphate pesticide chlorpyrifos affects form deprivation myopia. Invest Ophthalmol Vis Sci. 1998; 39(7): 1290-1294, indexed in Pubmed: 9620094.

18. luvone PM, Tigges M, Stone RA, et al. Effects of apomorphine, a dopamine receptor agonist, on ocular refraction and axial elongation in a primate model of myopia. Invest Ophthalmol Vis Sci. 1991; 35(5): 1674-1677, indexed in Pubmed: 2016144.

19. Rohrer B, Spira AW, Stell WK. Apomorphine blocks form-deprivation myopia in chickens by a dopamine D2-receptor mechanism acting in retina or pigmented epithelium. Vis Neurosci. 1993; 10(3): 447-453, doi: 10.1017/s0952523800004673, indexed in Pubmed: 8494798.

20. Schaeffel F, Bartmann $M$, Hagel $G$, et al. Studies on the role of the retinal dopamine/melatonin system in experimental refractive errors in chickens. Vision Res. 1995; 35(9): 1247-1264, doi: 10.1016/00426989(94)00221-7, indexed in Pubmed: 7610585.

21. Li XX, Schaeffel F, Kohler K, et al. Dose-dependent effects of 6-hydroxy dopamine on deprivation myopia, electroretinograms, and dopaminergic amacrine cells in chickens. Vis Neurosci. 1992; 9(5): 483-492, doi: $10.1017 / \mathrm{s} 0952523800011287$, indexed in Pubmed: 1360257.

22. Schaeffel F, Hagel G, Bartmann M, et al. 6-Hydroxy dopamine does not affect lens-induced refractive errors but suppresses deprivation myopia. Vision Res. 1994; 34(2): 143-149, doi: 10.1016/00426989(94)90327-1, indexed in Pubmed: 8116274.

23. Weiss S, Schaeffel F. Diurnal growth rhythms in the chicken eye: relation to myopia development and retinal dopamine levels. J Comp Physiol A. 1993; 172(3): 263-270, doi: 10.1007/BF00216608, indexed in Pubmed: 8510054.

24. Fisher AJ, Seltner RLP, Stell WK. Opiate and N-methyl-D-aspartate receptors in form-deprivation myopia. Visual Neurosci. 1998; 15(6): 1089-1096, doi: 10.1017/s0952523898156080, indexed in Pubmed: 9839973. 
25. Stone RA, Liu Ji, Sugimoto R, et al. GABA, experimental myopia, and ocular growth in chick. Invest Ophthalmol Vis Sci. 2003; 44(9): 39333946, doi: 10.1167/iovs.02-0774, indexed in Pubmed: 12939312.

26. Seltner RL, Rohrer B, Grant V, et al. Endogenous opiates in the chick retina and their role in form-deprivation myopia. Vis Neurosci. 1997; 14(5): $801-809$, doi: $10.1017 /$ s0952523800011548, indexed in Pubmed: 9364719.

27. Fujikado T, Kawasaki Y, Fujii J, et al. The effect of nitric oxide synthase inhibitor on form-deprivation myopia. Curr Eye Res. 1997; 16(10): 992996, doi: 10.1076/ceyr.16.10.992.9021, indexed in Pubmed: 9330850.

28. Fujikado T, Tsujikawa K, Tamura M, et al. Effect of a nitric oxide synthase inhibitor on lens-induced myopia. Ophthalmic Res. 2001; 33(2): 75-79, doi: 10.1159/000055647, indexed in Pubmed: 11244351.

29. Westbrook AM, Crewther SG, Beresford JA, et al. Formoguanamineinduced inhibition of deprivation myopia in chick is accompanied by choroidal thinning while retinal function is retained. Vision Res. 1995; 35(14): 2075-2088, doi: 10.1016/0042-6989(94)00282-q, indexed in Pubmed: 7660611.

30. Rada JA, Johnson JM, Achen VR, et al. Inhibition of scleral proteoglycan synthesis blocks deprivation-induced axial elongation in chicks. Exp Eye Res. 2002; 74(2): 205-215, doi: 10.1006/exer.2001.1113, indexed in Pubmed: 11950231.

31. Seltner RL, Stell WK. The effect of vasoactive intestinal peptide on development of form deprivation myopia in the chick: a pharmacological and immunocytochemical study. Vision Res. 1995; 35(9): 1265-1270, doi: 10.1016/0042-6989(94)00244-g, indexed in Pubmed: 7610586.

32. Roher B, Stell WK. Basic fibroblast growth factor (bFGF) and transforming growth factor (TGF-beta) act as stop and go signals to modulate postnatal ocular growth in the chick. Exp Eye Res. 1994; 58(5): 553-562, doi: 10.1006/exer.1994.1049, indexed in Pubmed: 7925692.

33. Iomdina N, Tarutta P, Semchishen V, et al. [Experimental realization of minimally invasive techniques of scleral collagen cross-linking]. Vestn Oftalmol. 2016; 132(6): 49-58, doi: 10.17116/oftalma2016132649-56, indexed in Pubmed: 28121299.

34. Siatkowski RM, Cotter S, Miller JM, et al. US Pirenzepine Study Group. Safety and efficacy of $2 \%$ pirenzepine ophthalmic gel in children with myopia: a 1-year, multicenter, double-masked, placebo-controlled parallel study. Arch Ophthalmol. 2004; 122(11): 1667-1674, doi: 10.1001/ archopht.122.11.1667, indexed in Pubmed: 15534128.

35. Tan DTH, Lam DS, Chua WH, et al. Asian Pirenzepine Study Group. One-year multicenter, double-masked, placebo-controlled, parallel safety and efficacy study of $2 \%$ pirenzepine ophthalmic gel in children with myopia. Ophthalmology. 2005; 112(1): 84-91, doi: 10.1016/j. ophtha.2004.06.038, indexed in Pubmed: 15629825.

36. Siatkowski RM, Cotter SA, Crockett RS, et al. U.S. Pirenzepine Study Group. Two-year multicenter, randomized, double-masked, placebocontrolled, parallel safety and efficacy study of $2 \%$ pirenzepine oph- thalmic gel in children with myopia. J AAPOS. 2008; 12(4): 332-339, doi: 10.1016/j.jaapos.2007.10.014, indexed in Pubmed: 18359651.

37. Trier K, Munk Ribel-Madsen S, Cui D, et al. Systemic 7-methylxanthine in retarding axial eye growth and myopia progression: a 36-month pilot study. J Ocul Biol Dis Infor. 2008; 1(2-4): 85-93, doi: 10.1007/ s12177-008-9013-3, indexed in Pubmed: 20072638.

38. Chia A, Chua WH, Cheung YB, et al. Atropine for the treatment of childhood myopia: safety and efficacy of $0.5 \%, 0.1 \%$, and $0.01 \%$ doses (Atropine for the Treatment of Myopia 2). Ophthalmology. 2012; 119(2): 347-354, doi: 10.1016/j.ophtha.2011.07.031, indexed in Pubmed: 21963266.

39. Azuara-Blanco A, Logan N, Strang N, et al. Low-dose (0.01\%) atropine eye-drops to reduce progression of myopia in children: a multicentre placebo-controlled randomised trial in the UK (CHAMP-UK)-study protocol. Br J Ophthalmol. 2020; 104(7): 950-955, doi: 10.1136/ bjophthalmol-2019-314819, indexed in Pubmed: 31653669.

40. Cheng J, Yang Y, Kong X, et al. The Effect of $0.01 \%$ Atropine Eye Drops on the Ocular Surface in Children for the Control of Myopia-The Primary Results from a Six-Month Prospective Study. Ther Clin Risk Manag. 2020; 16: 735-740, doi: 10.2147/TCRM.S265945, indexed in Pubmed: 32848404.

41. Guo L, Fan L, Tao J, et al. Use of Topical $0.01 \%$ Atropine for Controlling Near Work-Induced Transient Myopia: A Randomized, Double-Masked, Placebo-Controlled Study. J Ocul Pharmacol Ther. 2020; 36(2): 97-101, doi: 10.1089/jop.2019.0062, indexed in Pubmed: 31800355.

42. Li FF, Kam KaW, Zhang Y, et al. Differential Effects on Ocular Biometrics by $0.05 \%, 0.025 \%$, and $0.01 \%$ Atropine: Low-Concentration Atropine for Myopia Progression Study. Ophthalmology. 2020; 127(12): 1603-1611, doi: 10.1016/j.ophtha.2020.06.004, indexed in Pubmed: 32525048.

43. Fu A, Stapleton F, Wei Li, et al. Effect of low-dose atropine on myopia progression, pupil diameter and accommodative amplitude: low-dose atropine and myopia progression. Br J Ophthalmol. 2020; 104(11): 1535-1541, doi: 10.1136/bjophthalmol-2019-315440, indexed in Pubmed: 32086237.

44. Yam JC, Li FF, Zhang X, et al. Two-Year Clinical Trial of the LowConcentration Atropine for Myopia Progression (LAMP) Study: Phase 2 Report. Ophthalmology. 2020; 127(7): 910-919, doi: 10.1016/j. ophtha.2019.12.011, indexed in Pubmed: 32019700.

45. Grzybowski A, Armesto A, Szwajkowska M, et al. The Role of Atropine Eye Drops in Myopia Control. Curr Pharm Des. 2015; 21(32): 4718-4730, doi: 10.2174/1381612821666150909095403, indexed in Pubmed: 26350533.

46. Grzybowski A, Sobolewska B. Dobrowolsky from St. Petersburg and Hosch from Basel reported improvement of myopia after atropine use in 1868 and 1871. Strabismus. 2018; 26(1): 46, doi: 10.1080/092739 72.2017.1421675, indexed in Pubmed: 29293393. 